the remedial measures which have been devised to provide substantial protection in most cases that are encountered are described in an article by E. D. Sunde (Bell Lab. Rec., 21, No, 9 ; May 1943).

When lightning strikes, the current spreads in all directions from the point where it enters the earth, and if a cable is in the vicinity it will provide a lowresistance path so that much of the current will flow to the cable and in both directions along its sheath to remote points. The flow of current in the earth between the lightning channel and the cable may give rise to such a large voltage drop that the breakdown voltage of the soil is exceeded, particularly when the earth resistivity is bigh. The lightning stroke will then arc directly to the cable from the point where it enters the earth, often at the base of a tree. When this happens practically all the current reaches the cable sheath. Furrows so long as $100 \mathrm{ft}$. have been found in the earth along the path of such ares.

The current entering the sheath near the stroke point is attenuated as it flows toward remote points. The current leaving the sheath must flow through the adjacent soil, and the amount of this leakage current per unit length of cable is therefore smaller if the soil resistivity is high than if it is lcw; thus the current will travel farther the larger the earth resistivity. The flow of current along the sheath produces a voltage between the sheath and the core conductors, which is largest at the stroke point. This voltage is substantially equal to the resistance drop in the sheath between the stroke point and a point which is sufficiently remote so that the sheath current is negligible. Since the higher the earth resistivity, the farther will the current travel, this resistance drop will also increase with the earth resistivity. The maximum voltage between sheath and core is thus proportional to the sheath resistance and also to the square root of the earth resistivity. Carrier cables now being used are of smaller size and have a higher sheath resistance than full-size voicefrequency cables, and for this reason they are more subject to lightning damage, particularly when the earth resistivity is high.

Tests were made on the Stevens Point-Minneapolis cable, using a surge generator which generates a short-time surge of current similar to that of a lightning discharge but of much smaller magnitude. An earth was established remote from the cable, and the surge generator was connected between this earth and the cable sheath, and between the remoie earth and earths at distances of 10,25 , and $100 \mathrm{ft}$. from the cable. Results of the tests are given in the article.

When the voltage at the point where current enters the sheath is great enough to break down the insulation, the conductors and sheath are brought to essentially the same potential by the arcing. Under these conditions, the voltage between conductors and sheath increases with distance along the cable. A maximum is reached at some distance from the original fault, and beyond this point the voltage slowly decreases. After a puncture of the insulation where the current enters the sheath, other failures may therefore occur at some distance from this point in either or both directions. A single lightning stroke may thus cause insulation failures over a considerable distance along the cable.

One method of reducing failures caused by lightning strokes to buried cables is to increase the core insulation. This has been done for most new installations of buried cable. The cable itself, and such accessories as cable terminals and stubs, loading pots, and gasalarm contactors are all provided with sufficient extra insulation to double the dielectric strength between cable conductors and sheath. For a cable like the one on which measurements were made, such increased insulation would reduce the number of lightning strokes that could cause failure by direct arcing to the sheath to about 15 per cent of the total instead of 50 per cent, and would almost entirely eliminate the danger of breakdown when lightning strikes the earth as much as one hundred feet from the cable. Another method, which may be employed in addition to the extra insulation where excessive lightning damage would otherwise be expected, is to bury shield wires over the cable. These conduct away part of the lightning current and thus reduce the amount that flows along the sheath. These wires may be ploughed in with the cable, or they may be installed afterward. The percentage of the current carried by the wires depends to a greater extent on their inductance relative to that of the sheath than on their resistance. Two wires are employed in order to obtain a lower inductance than would be possible with a single wire.

On the route between Stevens Point and Minnea. polis where the shield wires were installed after the cable was in place, two 165-mil copper wires about $12 \mathrm{in}$. apart were ploughed in some $10 \mathrm{in}$. above the cable for a distance of 80 miles. Surge measurements made after these wires were installed indicated that the wires reduced the voltage between shenth and core conductors by about 60 per cent, which is in substantial agreement with theoretical expectations. The shield wires should thus reduce the number of direct lightning strokes that would be expected to cause failure to about 10 per cent, instead of 50 per cent without shield wires.

\section{PLANT DISEASES}

CEVERAL papers concerning plant diseases appear $N$ in a recent number of the Transactions of the British Mycological Society (26, Pts. 1 and 2 ; April 1943). Measurement of the intensity of plant disease in the field has occupied the attention of a subcommittee of the Society's plant pathology committee. The results indicate some rather suggestive lines of attack in the investigation of several diseases. A graph showing the incidence of potato blight at the Seale Hayne Agricultural College for different years, and for other localities for 1941, is very illuminating. The quick rise to a high degree of infection in 1932 is in marked contrast to the slow development of the disease in 1937, and merits further investigation. Other results are quite as suggestive. The sub-committee's main contribution, however, is in the standardization of methods, details of which are given in the paper.

W. C. Moore continues his series of descriptions of new and interesting plant pathogens. A disease of maize seedlings raised in nutrient solution was found to be caused by Fusarium moniliforme. It could be eliminated from the grain by soaking and heating to $54^{\circ} \mathrm{C}$. for $20 \mathrm{~min}$. A species of Penicillium, probably $P$. hirsutum, has also been assigned as the cause of a rot of Scilla bulbs, and Helminthosporium Allii is the pathogen of a bulb canker of garlic. This disease was discovered in an imported consignment before it could be planted, and so should not establish itself here. A brief note by $\mathrm{H}$. Duerden announces 
the appearance of Pythium mamillatum in England. It produces a damping-off disease of cress, similar to that caused by $P$. deBaryarum. Elizabeth Blackwell gives details of the very complex life-history of Phytophthora cactorum, a species with pathogenicity upon such widely differing genera as Cereus, Acer, Pyrus, Pæonia, Rheum, Fagus, Pinus and others. The species is paragynous and homothallic, and considerable progress in control of this parasite should result from this careful analysis of the many stages of its life-cycle.

In the realm of bacterial plant pathogens, W. J. Dowson publishes a list of species, with synonyms, which should be included in the genera Pseudomonas, Xanthornonas and Bacterium. This should be useful as it is difticult for the general pathologist to follow all the changes in modern bacterial nomenclature.

\section{FORTHCOMING EVENTS}

\section{Saturday, October 9}

Sheffigid Metallurgical Association (joint meeting with the MicRochemical SEgtion of THE Society of PUBLIC ANALYSTS and the SOUTH YORKSHIRE SECTION OF THE ROYAL INSTITUTE OF CHEMISTRY) (in the Department of Applied Science, The University, St. George's Square, Sheffield), at 2.30 p.m.-Symposium on "Microchemical Analysis",.

\section{Tuesday, October 12}

Society of Chemical Industry (Chemical Engineering Group AND LONDON SECTION) and the INSTITUTION OF CHEMICAL ENGINEERS (at the Institution of Mechanical Engineers, Storey's Gate, St. James's Park, London, S.W.1), at 2.30 p.m.-The Rt. Hon. Lord McGowan : "The Future of the Chemical Industry"

Royal Society of Mrdicine (at 1 Wimpole Street, London, W.1), at 5 p.m.-Dr. W. Norwood East: "The State, the Criminal and the Psychiatrist".

Chemical Society (LeEds AREa LOCAL SEOTION) (in the Chemistry Lecture Theatre, The University, Leeds), at 6.30 p.m.-Dr. E. H. Farmer: "Autoxidation in Relation to Olefinic Structure".

\section{Thursday, October 14}

INSTITUTE OF FUEL (at the Connaught Rooms, Great Queen Street, London, W.C.2), at 2.30 p.m.-Dr. E. S. Grumell: Melchett Lecture.

\section{Friday, October 15}

Physical Society (at the Royal Institution, Albemarle Street, Piccadilly, London, W.1), at 4.30 p.m.- The Rt. Hon. Lord Rayleigh, (Eighth Parsons Memorial Lecture).

ROYAL SOCIETY OF MEDicine (at 1 Wimpole Street, London, W.1) at 4.45 p.m.-Dr. N. S. Finzi : "Impending New Developments in Radiotherapy".

\section{Saturday, October 16}

INSTITUTE OF PHysios (X-RAY ANALYSIS GROUP) (joint meeting with the MANCHESTER AND DISTRICT BRANCH) (in the Physics Department, The University, Oxford Road, Manchester), at 2.30 p.m.Sir Lawrence Bragg, F.R.S. : "The Physical Optics of X-Ray Analysis" Problems.

\section{APPOINTMENTS VACANT}

APPLICATIONs are invited for the following appointments on or before the dates mentioned:

TEACHER oF CHEMISTRY for Junior Work in Technical Day School and Industrial and Intermediate B.Sc. Classes in the Technical College, a TEACHER OF MATHEMratics for Junior Work in Technical Day School and Technical and Intermediate B.Sc. Mathematics in the Technical College, and a TEACHER OF MECHANICAL ENGINEERING SUBJECTS up to Higher National Certiflcate standards, in the West Hartlepoo Technical College - The Chief Education Officer, Education Offices, Park Road, West Hartlepool (October 14).

Teacher of Mathematics aNd Physics in the Junior Technical School and Senior Part-time Classes in the Batley Technical CollegeThe Director of Education, Education Offices, Batley, Yorks. (October 15)

ADvisory OfFIcer IN Plant PATHology-The Secretary, West of Scotland Agricultural College, 6 Blythswood Square, Glasgow (October 15).

DIREOTOR OF ROBERT GORDON'S TECHNICAL COLLEGE-The Secretary, Robert Gordon's Technical College, Aberdeen (October 16).
Borough Electrical Engineer-The Town Clerk, Council Offices, Kettering (October 22).

Profrassor of ENGINGERING-The Registrar, University College, Singleton Park, Swansea (November 20).

Lecturer in Educational Psychology and Teaching Method The Principal, Gipsy Hill Training College for Teachers of Young Children, at Bankfiєld, Bingley, Yorks.

TEChNICAL Assistant in a Government Department in London for work connected with the planning of production of X-Ray Equipment-The Ministry of Labour and National Service, Central (Tech nical and Scientific) Register, Section D.562, Alexandra House, Kings way, London, W.C.2.

\section{REPORTS and other PUBLICATIONS}

(not included in the monthly Books Supplement)

\section{Great Britain and Ireland}

Medical Research Council: Industrial Health Research Board. Emergency Report No. 4: A Study of Absenteeism among Women. By Dr. S. Wyatt, R. Marriott and D. E. R. Hughes. Pp. 12. (London H.M. Stationery Office.) 2d. net. Industrial Research : What it Means to British Industry. By Sir City and Guilds of London Institute. Report of the Council to the Members of the Institute for the Year 1942. Pp. lvili. (London: Gresham College.)

Proceedings of the Royal Irish Academy. Vol. 49, Section B, No. 9: Salmon of the River Shannon. By Arthur E. J. Went. Pp. 151176. (Dublin: Hodges, Figgis and Co., Ltd. ; London: William and Norgate, Ltd.) 1s. $6 d$. Annual Reports on the Progress of Chemistry for 1942. Vol. 39. Pp. Xxviii +257. (London: Chemical Society.) 158. Henley Student, Manual. Pp. 28. (London: W. T. Henley's Tele-
graph Works Co., Ltd.) British Association for the Advancement of Science: Committee on Post-War University Education. Report on University Entrance Scholarships in England and Wales. Pp. 8. (London: British Associs. Scholarships in England and Wales. Pp. 8. (London: British Associa-
tion.) 6d. Board of Education. The Youth Service After the War : a Report of the Youth Advisory Council appointed by the President of the Board of Education in 1942 to advise him in questions relating to the Youth Service in England. Pp. 32. (London: H.M. Stationery Office.) 6d. net. The White Paper on Educational Reconstruccion and its Impact on Training for Mechanical Engineering. Pp. 8. (London: Institution of Mechanical Engineers.) [16] Handbook of the Scientific Instrument Manufacturers' Association of Great Britain, Ltd. Pp. $48+53$. (London: Scientific Instrumen Manufacturers' Association of Great Britain, Lta.) [20 The Liverpool and Stoke-on-Trent Railway Hour Section and als Birmingham and Nottingham Hour Sections to speed up Railways i the Midlands. By J. F. Pownall. Pp. 12. (Birmingham: Cottere] [208
Ministry of Agriculture and Fisheries. Growmore Bulletin No. 9: Ministry of Agriculture and fisherial Growers. By J. Turnbull. Pp

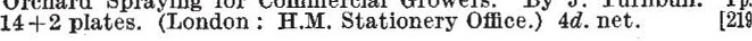

\section{Other Countries}

U.S. Department of the Interior: Geological Survey. WaterSupply Paper 873: Surface Water Supply of the United States, 1938 Part 3 : Ohio River Basin. Pp. xi $+578+1$ plate. 65 cents. Water Supply Paper 875 : Surface Water Supply of the United States, 1939 Part 5 : Hudson Bay and Upper Mississippi River Basins. Pp. xi+ $406+1$ plate. 50 cents. Water-Supply Paper 880 : Surface Water Supply of the United States, 1939. Part 10: The Great Basin. Pp. vi $+160+2$ plates. 25 cents. Water-Supply Paper 900: Surface Water Supply of the United States, 1940. Part 10: The Great Basin. Pp. iv $+126+1$ plate. 20 cents. Water-Supply Paper 901: Surface
Water Supply of the United States, 1940. Part 11: Pacific Slope Water Supply of the United States, 1940. Part 11: Paciflc Slope Basins in California. Pp. viii $+378+2$ plates. 50 cents. Water. Supply Paper 902: Surface Water Supply of the United States, 1940.
Part 12: Paciflc Slope Basins in Washington and Upper Columbis Part 12: Paciflc Slope Basins in Washington and Upper Columbia
River Basin. Pp. v $+210+1$ plate. 30 cents. Water-Supply Paper 903: Surface Water Supply of the United States, 1940. Part 13: Snake River Basin. Pp. vi $+246+1$ plate. 35 cents. Water-Supply Paper 904: Surface Water Supply of the United States, 1940. Part 14: Pacific Slope Basins in Oregon and Lower Columbia River Basin. Pp. $\mathrm{v}+208+1$ plate. 30 cents. Water-Supply Paper 910 : Water Levels and Artesian Pressure in Observation Wells in the United States in 1940. Part 5: Northwestern States. By O. E. Meinzer L. K. Wenzel, and others. Pp. iii + 184. 25 cents. (Washington, D.C.:
Government Printing Office.) Government Printing Office.)
War Department. Technical Manual TM. 10-420: Emergency Food Plants and Poisonous Plants of the Islands of the Paciflc. By Dr. E. D. Merrill. Pp. v +149 . (Washington, D.C.: Government Printing Office.)

Archæological Reconnaissance in Campeche, Quintana Rao, and Peten. By Karl Ruppert and John H. Denison, Jr. (Publication 543.) Pp. vii $+230+75$ plates. (Washington, D.C.: Carnegie In. stitution.) 4.25 dollars. Museum of Natural History. vol. 8, Art. 4: Physiological Aspect of Spring Diatom Flowerings. By Gordon A. Riley. Pp. 54. (Ne Haven, Conn.: Yale University.

Proceedings of the United States Natioral Museum. Vol. 93, No 3164: The Birds of Southern Veracruz, Mexico. By Alexander Wet more. Pp. 215-340. (Washington, D.C.: Government Printing 